\title{
Assessment of Bacterial Profile and Antimicrobial Resistance Pattern of Bacterial Isolates from Blood Culture in Addis Ababa Regional Laboratory, Addis Ababa, Ethiopia
}

Kumera Terfa Kitila ${ }^{1 *}$, Boja Dufera Taddese ${ }^{1}$, Tinsae K/mariam Hailu², Lemi Mosisa Sori ${ }^{3}$, Semira Ebrehim Geleto ${ }^{1}$, Gebeyahu Zeleke Mengistu ${ }^{2}$, Dawit Desta Tesfaw $^{2}$, Chalachew Sisay Gebeyehu², Hanna Mekonen Balcha ${ }^{2}$, Daniel Melese Desalegn ${ }^{1}$ and Abraham Tesfaye Bika ${ }^{2,4}$

${ }^{1}$ Ethiopia Public Health Institute (EPHI), Addis Ababa, Ethiopia

${ }^{2}$ City Government of Addis Ababa Public Health Research and Emergency Management, Addis Ababa, Ethiopia

${ }^{3}$ City Government of Addis Ababa Technical and Vocational Education Training Agency, Addis Ababa, Ethiopia

${ }^{4}$ Department of Microbial Cellular and Biology, College of Natural Sciences, Addis Ababa University, Addis Ababa, Ethiopia

"Corresponding authors: Kumera Terfa Kitila, Assistant Researcher II, Ethiopian Public Health Institute, National Laboratories Capacity Building Directorate, Addis Ababa, Ethiopia, Tel: +251912058200; E-mail: kumerat2012@gmail.com

Received date: April 5, 2018; Accepted date: April 23, 2018; Published date: April 28, 2018

Copyright: (C) 2018 Kitila KT, et al. This is an open-access article distributed under the terms of the Creative Commons Attribution License, which permits unrestricted use, distribution, and reproduction in any medium, provided the original author and source are credited.

\begin{abstract}
Background: Bacterial bloodstream infection is the major public health problem which leads to high morbidity and mortality of patients. Early diagnosis and appropriate treatments of bacterial blood stream infections are the best approach to reduce the patients' are becoming worsen conditions and to prevent the developments of drug resistance bacteria. The aim of this study was to determine the bacterial profile of blood stream infections and their antibiotic resistance pattern in Addis Ababa, Ethiopia.
\end{abstract}

Methods: Records of 500 patients blood culture result from Clinical Microbiology laboratory unit of Addis Ababa Regional Laboratory was reviewed from January, 2015 to December, 2016. Data was entered and analysed by using SPSS version 20.0 statistical software and results were expressed using frequency and percentages. Tables and graphs were used to summarize the results. The chi-square test was employed to assess the association between variables. A p-value of less than 0.05 was considered as statistically significant.

Results: Out of 500 blood culture results reviewed, among these the frequency of blood culture positive was 164 $(32.8 \%)$. Out of a total 164 isolates, $127(77.4 \%)$ were gram-positive bacteria and $37(22.6 \%)$ were gram-negative bacteria. The predominant bacteria species isolated comprise Staphylococcus aureus $82(50.0 \%)$, Coagulase negative staphylococci (CONS) 43 (26.21\%), Klebisella pneumoniae $23(14.02 \%)$, Escherichia coli 6 (3.6\%), Acinobacter baumannii $4(2.4 \%)$, Streptococcus species $3(1.8 \%)$, Pseudomonas aeruginosa $2(1.2 \%)$ and Nesseriae meningitidis $1(0.6 \%)$. Generally, in this study majority of gram-positive isolates showed high resistance to commonly used antimicrobials to Penicillin(83.5\%), Trimethoprim-sulphamethoxazole (83.5\%), Erythromycin (77.3\%), Doxycycline (76.5\%), Tetracycline $(76.5 \%)$, Gentamycin $(75.0 \%)$, and least resistant to Clindamycin $(5.4 \%)$ and Chloramphenicol (46.1\%) and high resistant gram-negative isolates was seen to Ampcillin (88.5\%),Amoxicillinclavulanic acid $(80 \%)$, Trimethoprim-sulphamethoxazole $(80 \%)$, Ceftriaxone $(77.1 \%)$ and least resistant to Ceftriaxone $(42.8 \%)$ and Cefepime $(51.5 \%)$. In this study it was also revealed that isolated bacteria species developed multi drug resistance to most of the antibiotics commonly tested.

Conclusions: In this study the overall blood culture positive bacterial isolate rate was high $(32.8 \%)$. The most predominant blood culture isolates were Staphylococcus aureus, Coagulase negative staphylococci and Klepsiella pneumonia. Antibiotic resistances of isolates were alarmingly high so that proper management of patients with blood stream infections needs careful selection of effective antibiotics.

Keywords: Antimicrobial resistance; Bacterial profile; Blood stream infections; Blood culture; Ethiopia

\section{Introduction}

Bloodstream infection (BSI) remains one of the main causes of morbidity and mortality, ranging from self-limiting to life threatening sepsis that requires rapid antimicrobial treatment [1]. However, the problem is still common in developed nations, with highest burden in sub Saharan countries including Ethiopia [2]. Antimicrobial resistance $(A M R)$ is an emerging and serious public health threat in both developed and developing countries, though the problem is still common in developed nations, the burden is high in sub Saharan countries $[3,4]$.

Now days, AMR bacteria is an emerging serious public health threat in both developed and developing countries [5,6]. Different reports have shown antibiotics resistance arises as a consequence of mutations in the genomes of microbes and improper selection of antibiotic used for treatment which provides a competitive advantage for mutated strains $[6,7]$. 
Citation: Kitila KT, Taddese BD, Hailu TK, Sori LM, Geleto SE, et al. (2018) Assessment of Bacterial Profile and Antimicrobial Resistance Pattern of Bacterial Isolates from Blood Culture in Addis Ababa Regional Laboratory, Addis Ababa, Ethiopia. Clin Microbiol 7: 312 . doi: $10.4172 / 2327-5073.1000312$

Page 2 of 6

Monitoring and controlling AMR is challenging especially in developing countries, due to lack of surveillance systems, limited resources, poor adherence to infection control measures, use of antibiotics without physician prescription and limited antimicrobial formularies [8].

The prevalence of antibiotic resistance among the bacteria that cause blood stream infections are getting increased day by day alarmingly, hence rendering common infections either more difficult to treat or untreatable, resulting in devastating consequences to patients [9].

Antimicrobial resistance is global concern yet, on other hand, there are few reports from Ethiopia, where the antimicrobial choices are often limited and diagnostic laboratory facilities for antibacterial resistance evaluations are inadequate due to cost, laboratory infrastructure and trained personnel constraint in developing country $[8,10]$.

Therefore, this study was aimed to describe the bacterial agents associated with BSI and their antimicrobial resistance patterns in study area and hence provide the update information to concerned body and the scientific community will also be attracted by the findings to carry out rigorous researches in this thematic area.

\section{Methods}

\section{Study design, study area and Study population}

A descriptive cross sectional study was conducted based on the two years records of culture and drug susceptibility test results of blood in the clinical microbiology laboratory unit from January, 2015 to December, 2016 in Addis Ababa, Ethiopia. This study was conducted in Addis Ababa regional laboratory, Addis Ababa, Ethiopia, which is the only regional laboratory under Addis Ababa city Administration health bureau providing different high level laboratory examinations requested from different health facilities of the city for an estimated total population of $3,384,569$, with annual growth rate of $3.8 \%$. All patients' data of blood culture and antimicrobial sensitivity test result from clinical microbiology laboratory during the study period were included.

\section{Sampling technique and data collection}

All patient data from patient recorded log books of blood culture and antimicrobial sensitivity test results for the specific pathogen isolated in the clinical microbiology laboratory unit from January 2015 to December 2016 was included in the study. Data was collected using structured data abstraction format developed by the principal investigators. All the information including blood culture results and antibiotic sensitivity for isolated pathogens was collected.

Data on Socio-demographic variables blood culture results and antibiotic susceptibility pattern was collected manually using pre prepared data abstraction format. Two blood samples were collected according to SOPs before the patients any antibiotic treatment. Before vein puncture the site was disinfected with $70 \%$ alcohol and $2 \%$ tincture of iodine and approximately $10 \mathrm{ml}$ of blood was collected and around $5 \mathrm{ml}$ of blood was inoculated into each of $50 \mathrm{ml}$ of Tryptone soya broth (Oxoid UK).

Biochemical test including catalase, Coagulase, novobiocin and optochin disk for gram positive and triple sugar iron, indole, citrate, urea, Lysine decarboxylase (LDC) and motility was done for gram negative bacteria following standard procedures. Susceptibility testing was performed on Muller Hinton agar (Oxoid, Hampshire, UK) using agar disc diffusion method [11-13].

Ampicillin (AMP) $(10 \mu \mathrm{g})$, Amoxicillin (AMC) $(30 \mu \mathrm{g})$, Ceftriaxone (CRO) $(30 \mu \mathrm{g})$, Cefepime (CFP) $(30 \mu \mathrm{g})$, Ceftriaxone (CRO) $(30 \mu \mathrm{g})$, Cefoxitin (CTX) $(30 \mu \mathrm{g})$, Cefutaxime (CTX) $(30 \mu \mathrm{g})$; Cefotetan (CTT) $(30 \mu \mathrm{g})$, Chloramphenicol (CHL) $(30 \mu \mathrm{g})$, Ciprofloxacin (CIP) $(5 \mu \mathrm{g})$, Clarithromycin (CLM) $(15 \mu \mathrm{g})$; Erythromycin (E) $(15 \mu \mathrm{g})$, Gentamycin (GEN) $(10 \mu \mathrm{g})$, Penicillin (P) $(10 \mu \mathrm{g})$, Piperacillin (PPC) $(100 \mu \mathrm{g})$, Piperacillin-Tazobactam (PPT) $(100 / 10 \mu \mathrm{g})$, Tobramycin (TOB) $(10$ $\mu \mathrm{g})$ :, Trimethoprim-Sulphamethoxazole (SXT) $(25 \mu \mathrm{g})$, Ticarcillinclavunate (TCL) $(75 / 10 \mu \mathrm{g})$ : and Tetracycline (TTC) $(30 \mu \mathrm{g})$, meropenem $(10 \mu \mathrm{g})$, ertapenem $(10 \mu \mathrm{g})$, oxacillin $(1 \mu \mathrm{g})$ cefotaxime $(30 \mu \mathrm{g})$ and ceftazidime $(30 \mu \mathrm{g})$ were the antibiotics used for disk diffusion test. The results of diffusion test were interpreted according to the National Committee for Clinical Laboratory Standards (NCCLS). Escherichia coli (ATCC 25922), Staphylococcus aureus (ATCC 25923) and Pseudomonas aeroginosa (ATCC 27853) was used as reference strains for culture and susceptibility testing [11].

\section{Data managements and quality assurance}

Before data collection the investigators provided training for data collectors and necessary technical support, coordinated, monitored on the overall data collection process and procedures to ensure data quality and completeness. Data was entered and analysed using SPSS version 20.0 statistical software and results was expressed using frequency and percentages. Figures and tables were used to summarize results. The chi-square test was employed to assess the association between variables. A p-value of less than 0.05 was considered as statistical significant.

\section{Results}

A total of 500 blood culture specimens from patients with suspected bacteraemia were processed from January 2015 to December 2016. Of these patients $231(46.2 \%)$ were females and 259 (51.8\%) were males, the age of the patients were ranged from a day to 86 years. majority of the patients $264(52.8 \%)$ were less than one year. The overall prevalence of blood culture positive of bacteraemia suspected patients was $164 / 500$ (32.8\%). Of these culture positive samples 98/259 (37.8\%) were males and 66/231 (28.6\%) were females (Table 1). Of the culture positive results $128 / 164(78.04 \%)$ were gram positive and $36 / 164$ (21.95\%) were gram negative bacteria.

Among total of 164 isolates the most predominantly isolated bacteria species that causing blood stream infection, 82 (50.00\%) were Staphylococcus aureus, 43 (26.21\%) were Coagulase negative Staphylococcus (CoNS), 23 (14.02\%) were Klebsiella pneumonia, 6 (3.6\%.) were Escherichia coli, 4 (2.4\%) were Acinobacter baumannii, $3(1.8 \%)$ were Streptococcus species, $2(1.2 \%)$ were $P$. aeruginosa and 1(0.6\%) were Nesseria meningitides (Figure 1).

Among gram positive isolates 82 (64.56\%) was Staphylococcus species, 43 (33.85\%) was Coagulase negative Staphylococcus (CoNS), 3 $(2.36 \%)$ was Streptococcus species and of the total of 36 gram negative bacteria isolates constituted 23 (63.90\%), 6 (16.71\%), 4 (11.11\%), 2 (5.5\%), and 1 (2.77\%) were Klebsiella pneumoniae, Escherichia coli, Acinetobacter baumannii, Pseudomonas aeruginosa and Nesseria meningitides respectively. 
Citation: Kitila KT, Taddese BD, Hailu TK, Sori LM, Geleto SE, et al. (2018) Assessment of Bacterial Profile and Antimicrobial Resistance Pattern of Bacterial Isolates from Blood Culture in Addis Ababa Regional Laboratory, Addis Ababa, Ethiopia. Clin Microbiol 7: 312 . doi: $10.4172 / 2327-5073.1000312$

Page 3 of 6

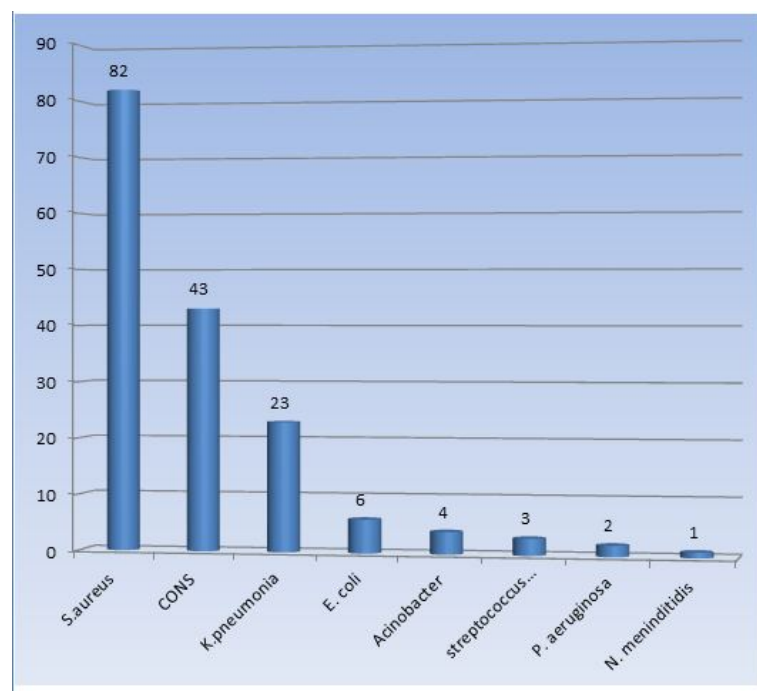

Figure 1: Frequency of bacterial species isolates from blood stream infected patients recovered from blood culture (BSI) January 2015 to December 2016.
Antibacterial Sensitivity test results showed that gram positive bacteria, Staphylococcus aureus $70 / 82(85.4 \%)$ was resistance to Trimethoprim-sulphamethoxazole, $68 / 82(82.9 \%)$ was resistance to Penicillin, 62/82 (75.6\%) was resistance to Erythromycin, 61/82 (74.3\%) was resistance to Tetracycline, $61 / 82(74.3 \%)$ was resistance to Doxycycline, $60 / 82(73.1 \%)$ was resistance to Gentamycin and 55/82 (67.1\%) was resistance to Clarithromycin whereas majority of Staphylococcus aureus showed least resistance to Chloramphenicol and Clindamycin which was 38/82 (46.3\%) and 4/82 (4.8\%) respectively. Another gram positive isolates CoNS also showed high resistance to Penicillin, Co-trimoxazole Doxycycline, Tetracycline, Erythromycin and Gentamycin which was (38/43 (90.5\%), 36/43 (85.7\%), 36/43 (85.7\%), 36/43 (85.7\%), 35/43 (83.3\%), 38/43 (83.3\%)) respectively. Streptococcus species was showed no resistance to almost all antibacterial drugs used for antibacterial susceptibility test (Table 2). Among gram negative isolates Klebsiella pneumoniae showed $23 / 23$ (100\%), 21/23 (91.3\%), and 20/23 (86.9\%) were resistance to Ampicillin, Amoxicillin-clavunate, and Trimethoprimsulphamethoxazole respectively. E. coli isolates showed also high resistance to Ampicillin, Amoxicillin-clavunate, and Trimethoprimsulphamethoxazole, while moderate resistance showed to Tetracycline and cefotetan. Majority of gram negative isolates were showed more sensitive to Ciprofloxacin, Cefepime, Cefotetan and Gentamycin drugs relatively (Table 3). All infections isolated during study period were monomicrobial.

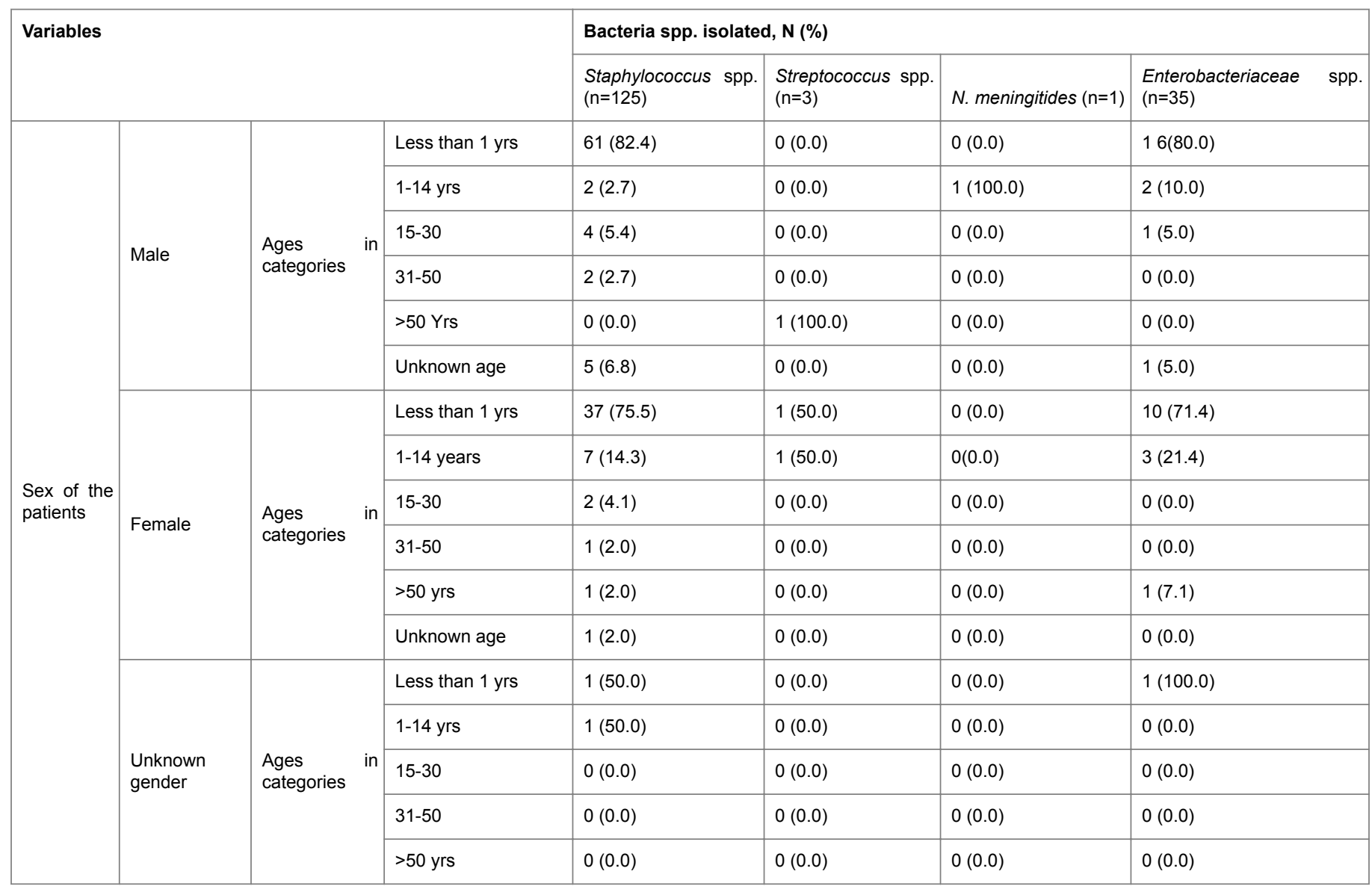


Citation: Kitila KT, Taddese BD, Hailu TK, Sori LM, Geleto SE, et al. (2018) Assessment of Bacterial Profile and Antimicrobial Resistance Pattern of Bacterial Isolates from Blood Culture in Addis Ababa Regional Laboratory, Addis Ababa, Ethiopia. Clin Microbiol 7: 312 . doi: $10.4172 / 2327-5073.1000312$

Page 4 of 6

\begin{tabular}{|l|l|l|l|l|l|l|l|}
\hline & & & Unknown age & $0(0.0)$ & $0(0.00$ & $0(0.0)$ & $0(0.0)$ \\
\hline
\end{tabular}

Table 1: Showing sex and age distribution frequency of bacterial species isolated from patients with blood stream infections (BSI) January 2015 to December 2016, Addis Ababa, Ethiopia.

\begin{tabular}{|c|c|c|c|c|c|c|c|c|c|c|c|c|c|c|}
\hline \multirow{2}{*}{$\begin{array}{l}\text { Isolated } \\
\text { Organisms No. }\end{array}$} & \multicolumn{14}{|c|}{ Resistance of Antibiotics tested No (\%) } \\
\hline & $\mathbf{P}$ & CLD & CLM & ERY & SXT & DOX & $T$ & CIP & $\mathrm{CHL}$ & GEN & AMP & CRO & CTX & CFP \\
\hline $\begin{array}{l}\text { Staphylococcus } \\
\text { aureus }(n=82)\end{array}$ & $\begin{array}{l}68 \\
(82.90)\end{array}$ & $4(4.80)$ & $\begin{array}{l}55 \\
(67.10)\end{array}$ & $\begin{array}{l}62 \\
(75.60)\end{array}$ & $\begin{array}{l}70 \\
(85.40)\end{array}$ & $\begin{array}{l}61 \\
(74.30)\end{array}$ & $\begin{array}{l}61 \\
(74.30)\end{array}$ & $\begin{array}{l}49 \\
(59.70)\end{array}$ & $\begin{array}{l}38 \\
(46.30)\end{array}$ & $\begin{array}{l}60 \\
(73.10)\end{array}$ & NA & NA & NA & NA \\
\hline $\begin{array}{l}\text { Coagulase negative } \\
\text { Staph. }(n=43)\end{array}$ & $\begin{array}{l}38 \\
(90.50)\end{array}$ & $2(4.70)$ & $\begin{array}{l}23 \\
(54.70)\end{array}$ & $\begin{array}{l}35 \\
(83.30)\end{array}$ & $\begin{array}{l}36 \\
(85.70)\end{array}$ & $\begin{array}{l}36 \\
(85.70)\end{array}$ & $\begin{array}{l}36 \\
(85.70)\end{array}$ & $\begin{array}{l}20 \\
(47.60)\end{array}$ & $\begin{array}{l}20 \\
(47.60)\end{array}$ & $\begin{array}{l}35 \\
(83.30)\end{array}$ & NA & NA & NA & NA \\
\hline \multicolumn{15}{|c|}{ Streptococcus spps $(\mathrm{n}=3)$} \\
\hline S. Pyogens $(n=1)$ & $0(0.0)$ & $0(0.0)$ & $0(0.0)$ & $0(0.0)$ & $0(0.0)$ & $0(0.0)$ & $0(0.0)$ & $0(0.0)$ & $0(0.0)$ & $0(0.0)$ & $\begin{array}{l}1 \\
(100.0)\end{array}$ & $0(0.0)$ & $0(0.0)$ & $0(0.0)$ \\
\hline $\begin{array}{l}\text { Enterococcus } \\
\text { fecalis }(\mathrm{n}=1)\end{array}$ & $\begin{array}{l}1 \\
(100.0)\end{array}$ & $\begin{array}{l}1 \\
(100.0)\end{array}$ & $0(0.0)$ & $\begin{array}{l}1 \\
(100.0)\end{array}$ & $0(0.0)$ & $0(0.0)$ & $0(0.0)$ & $0(0.0)$ & $0(0.0)$ & $0(0.0)$ & $0(0.0)$ & $0(0.0)$ & $\begin{array}{l}1 \\
(100.0)\end{array}$ & $0(0.0)$ \\
\hline S. smilleris $(\mathrm{n}=1)$ & $0(0.0)$ & $0(0.0)$ & $\begin{array}{l}1 \\
(100.0)\end{array}$ & $0(0.0)$ & $1(100.0)$ & $\begin{array}{l}1 \\
(100.0)\end{array}$ & $\begin{array}{l}1 \\
(100.0)\end{array}$ & $\begin{array}{l}1 \\
(100.0)\end{array}$ & $\begin{array}{l}1 \\
(100.0)\end{array}$ & $\begin{array}{l}1 \\
(100.0)\end{array}$ & $\begin{array}{l}1 \\
(100.0)\end{array}$ & $\begin{array}{l}1 \\
(100.0)\end{array}$ & $\begin{array}{l}1 \\
(100.0)\end{array}$ & $\begin{array}{l}1 \\
(100.0)\end{array}$ \\
\hline Total $(n=128)$ & $\begin{array}{l}107 \\
(83.5)\end{array}$ & $7(5.4)$ & $\begin{array}{l}89 \\
(69.5)\end{array}$ & $\begin{array}{l}99 \\
(77.3)\end{array}$ & $\begin{array}{l}107 \\
(83.5)\end{array}$ & $\begin{array}{l}98 \\
(76.5)\end{array}$ & $\begin{array}{l}98 \\
(76.5)\end{array}$ & $\begin{array}{l}70 \\
(54.6)\end{array}$ & $\begin{array}{l}59 \\
(46.1)\end{array}$ & $\begin{array}{l}96 \\
(75.0)\end{array}$ & $2(66.6)$ & $1(33.3)$ & $2(66.6)$ & $1(33.3)$ \\
\hline
\end{tabular}

Table 2: Antibiotics resistance patterns of Gram positive bacteria isolated from patients with blood stream infection From January 2015 to December 2016, Addis Ababa, Ethiopia.

\begin{tabular}{|c|c|c|c|c|c|c|c|c|c|c|c|c|c|c|c|c|c|c|}
\hline \multirow{2}{*}{$\begin{array}{l}\text { Isolated } \\
\text { Organisms } \\
\text { No. }\end{array}$} & \multicolumn{18}{|c|}{ Resistance of Antibiotics tested No (\%) } \\
\hline & AMP & GEN & $\begin{array}{l}\text { AMC- } \\
\text { AUG }\end{array}$ & CFP & CTX & CRO & CTT & CRX & IMP & CPR & SXT & CAZ & CHL & $T$ & TCL & PPC & PPT & TOB \\
\hline $\begin{array}{l}\text { K. } \\
\text { pneumonia } \\
(\mathrm{n}=23)\end{array}$ & $\begin{array}{l}23 \\
(100)\end{array}$ & $\begin{array}{l}13 \\
(56.5)\end{array}$ & \begin{tabular}{|l|}
21 \\
$(91.3)$
\end{tabular} & $\begin{array}{l}11 \\
(47.8)\end{array}$ & \begin{tabular}{|l|}
14 \\
$(60.8)$
\end{tabular} & $\begin{array}{l}20 \\
(86.9)\end{array}$ & \begin{tabular}{|l|}
10 \\
$(43.5)$
\end{tabular} & \begin{tabular}{|l|}
14 \\
$(60.8)$
\end{tabular} & \begin{tabular}{|l|}
16 \\
$(69.5)$
\end{tabular} & \begin{tabular}{|l|}
9 \\
$(39.1$ \\
)
\end{tabular} & $\begin{array}{l}20 \\
(86.9)\end{array}$ & $\begin{array}{l}18 \\
(78.3)\end{array}$ & \begin{tabular}{|l}
14 \\
$(60.8)$
\end{tabular} & \begin{tabular}{|l}
17 \\
$(73.9)$
\end{tabular} & NA & NA & NA & NA \\
\hline E. coli $(\mathrm{n}=6)$ & $\begin{array}{l}5 \\
(83.3)\end{array}$ & $\begin{array}{l}3 \\
(50.0)\end{array}$ & \begin{tabular}{|l|}
4 \\
$(66.6)$
\end{tabular} & $\begin{array}{l}3 \\
(50.0)\end{array}$ & $\begin{array}{l}3 \\
(50.0)\end{array}$ & $\begin{array}{l}3 \\
(50.0)\end{array}$ & $\begin{array}{l}2 \\
(33.30 \\
)\end{array}$ & $\begin{array}{l}4 \\
(66.60 \\
)\end{array}$ & $\begin{array}{l}3 \\
(50.0)\end{array}$ & \begin{tabular}{|l|}
3 \\
$(50.0$ \\
)
\end{tabular} & $\begin{array}{l}5 \\
(83.30 \\
)\end{array}$ & $\begin{array}{l}3 \\
(50.0)\end{array}$ & $\begin{array}{l}3 \\
(50.0)\end{array}$ & $\begin{array}{l}2 \\
(33.30 \\
)\end{array}$ & NA & NA & NA & NA \\
\hline $\begin{array}{l}\text { Acinetobacte } \\
r(\mathrm{n}=4)\end{array}$ & $\begin{array}{l}3 \\
(75.0)\end{array}$ & $\begin{array}{l}3 \\
(75.0)\end{array}$ & \begin{tabular}{|l|}
3 \\
$(75.0)$
\end{tabular} & $\begin{array}{l}3 \\
(75.0)\end{array}$ & $\begin{array}{l}3 \\
(75.0)\end{array}$ & $\begin{array}{l}4 \\
(100.0 \\
)\end{array}$ & $\begin{array}{l}3 \\
(75.0)\end{array}$ & $\begin{array}{l}4 \\
(100.0 \\
)\end{array}$ & $\begin{array}{l}4 \\
(100.0 \\
)\end{array}$ & \begin{tabular}{|l|}
1 \\
$(25.0$ \\
)
\end{tabular} & $\begin{array}{l}3 \\
(75.0)\end{array}$ & $\begin{array}{l}3 \\
(75.0)\end{array}$ & $\begin{array}{l}4 \\
(100.0 \\
)\end{array}$ & $\begin{array}{l}3 \\
(75.0)\end{array}$ & NA & NA & NA & NA \\
\hline $\begin{array}{l}P \text {. } \\
\text { aeruginosa } \\
(n=2)\end{array}$ & NA & \begin{tabular}{|l}
1 \\
$(50.0)$
\end{tabular} & NA & $\begin{array}{l}1 \\
(50.0)\end{array}$ & NA & NA & NA & NA & 0 & \begin{tabular}{|l|}
1 \\
$(50.0$ \\
)
\end{tabular} & NA & \begin{tabular}{|l}
1 \\
$(50.0)$
\end{tabular} & NA & NA & $\begin{array}{l}1 \\
(50.0 \\
)\end{array}$ & $\begin{array}{l}2 \\
(100.0 \\
)\end{array}$ & $\begin{array}{l}1 \\
(50.0 \\
)\end{array}$ & $\begin{array}{l}2 \\
(100.0 \\
)\end{array}$ \\
\hline Total $(n=35)$ & \begin{tabular}{|l}
31 \\
$(88.5)$
\end{tabular} & \begin{tabular}{|l}
20 \\
$(57.10$ \\
)
\end{tabular} & \begin{tabular}{|l|}
28 \\
$(80.0)$
\end{tabular} & $\begin{array}{l}18 \\
(51.50 \\
)\end{array}$ & $\begin{array}{l}20 \\
(57.10 \\
)\end{array}$ & $\begin{array}{l}27 \\
(77.10 \\
)\end{array}$ & $\begin{array}{l}15 \\
(42.80 \\
)\end{array}$ & $\begin{array}{l}22 \\
(62.80 \\
)\end{array}$ & $\begin{array}{l}23 \\
(65.70 \\
)\end{array}$ & \begin{tabular}{|l|}
14 \\
$(40.0$ \\
)
\end{tabular} & $\begin{array}{l}28 \\
(80.0)\end{array}$ & $\begin{array}{l}22 \\
(62.80 \\
)\end{array}$ & $\begin{array}{l}21 \\
(60.0)\end{array}$ & $\begin{array}{l}22 \\
(62.80 \\
)\end{array}$ & $\begin{array}{l}1 \\
(50.0 \\
)\end{array}$ & $\begin{array}{l}2 \\
(100.0 \\
)\end{array}$ & $\begin{array}{l}1 \\
(50.0 \\
)\end{array}$ & $\begin{array}{l}2 \\
(100.0 \\
)\end{array}$ \\
\hline
\end{tabular}

Table 3: Show Antibiotics resistance pattern of Gram Negative bacteria isolated from patients of blood stream infection From January 2015 to December 2016, Addis Ababa, Ethiopia. 
Citation: Kitila KT, Taddese BD, Hailu TK, Sori LM, Geleto SE, et al. (2018) Assessment of Bacterial Profile and Antimicrobial Resistance Pattern of Bacterial Isolates from Blood Culture in Addis Ababa Regional Laboratory, Addis Ababa, Ethiopia. Clin Microbiol 7: 312. doi: $10.4172 / 2327-5073.1000312$

Page 5 of 6

\section{Discussion}

In this study the overall frequency of bacteria isolated from blood culture was 164 (32.8\%). This was comparable with study conducted in Mekelle, Ethiopia was 28\% [2]. The current study was higher than study reported from different area of Ethiopia, 21.4\% in Addis Ababa, $18.2 \%$ in Gonder, $8.8 \%$ in Jimma $[4,13,14]$ and in Nigeria $18.2 \%$ [15], two study from India $24.8 \%$ and $22.3 \%$ [16,17]. Most possible explanation could be due to the difference in blood culture system, study population, the study design, geographical location, etiological agents, and infection control policies between countries $[2,13,24]$. Seventy seven $\%$ of our findings showed that BSI was caused by GPB and $22.6 \%$ was caused by GNB. Similar Study findings also reported that higher BSI caused by GPB than GNB organisms reported from Ethiopia (72.2\% vs. $27.8 \%)$ and (69\% vs. 31\%) [2,14]. Another study reported from India was (53\% vs. $39 \%)$ and $(59.3 \%$ vs. $29.6 \%)$ also showed higher BSI caused by GPB than GNB respectively $[16,17]$.

This study revealed that $S$. aureus and CoNS were the first and second most prevalent GPB agents isolated in this study area. This has also been reported by other studies conducted in different areas $[1,2,14,16]$. The probable reason for highest incidence of these bacteria could be commonly found in the hospital environment which might be contaminate among admitted patients and increase the infection rate [16]. $K$. pneumoniae and $E$. coli was the predominant isolated GNB with prevalence rates of $(14.02 \%$ and $3.6 \%)$ respectively. This finding was comparable to study from Addis Ababa, Ethiopia where isolation rate of Klebsiella spp. and E. coli were $(9.7 \%)$ and (8.1\%) respectively [4]. The results of this study showed that BSI was more prevalent in under one year's old ages than adults. This finding is supported by different other studies $[13,14,16]$. There was a statistically significant association between age of patients and $\mathrm{BSI}(\mathrm{P}<0.001)$, indicating that high BSI was seen in less than one year age group especially in neonates. This is comparable with study reported from different area $[14,18]$. This is might be due to their low immune response, socioeconomic status of their parents, poor hygiene practices, may be bottle feeding and few of them may be give birth at home which may contaminate the infants easily and get infections $[1,2,4]$.

Although, this study showed that males were more infected than females $(37.8 \%$ vs. $28.6 \%)$ respectively, there was no statistically significant difference in gender variation $(\mathrm{P}=0.928)$ in this study. This slight variation has been previously reported by various studies .It is not exactly clear why there was predominant $[14,19]$.

In this study another important point was antimicrobial resistance rate was high and this is may be causes a serious therapeutic challenge to the management of common infections. It has also indicated that most resistance range for both gram positive and gram negative organisms was ranges from ( $4.8 \%$ to $85.4 \%$ and $40 \%$ to $100 \%)$ respectively. Most of the GNB were multi drug resistance with a very high resistance to betalactam antibiotics (80\% resistant to AmoxillinClavunate, $62.8 \%$ resistant to Ceftazidime and $57.1 \%$ resistant to Cefotaxime). Third generation cephalosporins showed a very weak activity against them. Carbapenem resistance was detected in $100 \%$ isolates of Acinetobacter spp., 69.5\% of Klebsiella pneumonia and 50\% of $E$. coli. Yet, in this study (94.6\%) of GPB was sensitive to Clindamycin and GNB was sensitive to Ciprofloxacin (60\%) and to Cefotetan (57.2\%) which was comparable with other studies in Ethiopia [14,20], in Zambia [21], in India [16], and in Nigeria [19]. In this study, $84.5 \%$ strains of Staphylococci spps showed resistance to Penicillin. Penicillin resistant $S$. aureus is usually treated with cloxacillin or nafcillin, but the upsetting reality is the emergence of
MRSA. In this study, the rate of MRSA strains was $72 \%$. This study comparable with study reported from Ethiopia, Nigeria and India $[1,2,19]$. This high resistance of both GPB and GNB could be due to frequent use of these drugs, as these drugs being the first line drugs in infections cases, inappropriate use of antibiotics and few people selfprescribing antibiotics and treatment by the patients due to availability of antibiotics on the market in the study area $[19,22]$. Since this is retrospective study, the study population was not systematically selected, and a relatively low number of cultures were performed over the study time-period the results may not be truly representative and isolations of Candida species was not done due to media scarcity [23-24].

\section{Conclusion}

In this study the overall prevalence of blood stream infection was high (32.8\%). AMR is alarming and a major problem in the management of blood stream infection. Therefore timely investigation of bacteria that cause infections and monitoring of their antibiotic susceptibility pattern is very important to reduce the incidence of BSI and drug resistant strains, it is also important to keep constant of antibiotics sensitivity surveillance on blood culture isolates and ensuring more rational drug use and combination of antibiotic therapy may help to check the emergence of resistance.

\section{Limitations}

- Since it is retrospective study, the study population was not systematically selected, so that the results may not be truly representative.

- The laboratory test method was simply classical/phenotypic and isolation of Candida species was not done due to media scarcity.

\section{Declarations}

\section{Ethics approval and consent to participate}

Ethical clearance and approval was obtained from the Ethical review committee of Addis Ababa Public health research and Emergency management (AAPHREM). In addition, the official letter of cooperation granted by Addis Ababa city administration health bureau to the Clinical Microbiology unit, we kept the privacy and confidentiality of the study participants' data throughout the study.

\section{Availability of data and material}

The data sets generated during the current study are available from the corresponding author on reasonable request.

\section{Competing interests}

The authors declare that, they have no competing interest.

\section{Consent for publication}

Not applicable

\section{Funding}

The authors had no funding support or funding to report. 
Citation: Kitila KT, Taddese BD, Hailu TK, Sori LM, Geleto SE, et al. (2018) Assessment of Bacterial Profile and Antimicrobial Resistance Pattern of Bacterial Isolates from Blood Culture in Addis Ababa Regional Laboratory, Addis Ababa, Ethiopia. Clin Microbiol 7: 312. doi: $10.4172 / 2327-5073.1000312$

Page 6 of 6

\section{Authors' contributions}

KT conceived and designed the study protocol, participated in data collection, performed analysis, interpretation of data, drafted and finalized the manuscript for publication, SE, GZ, DD were assisted in data collection and BD, TK, CS, HM, YW, DM, AT reviewed the initial and final drafts of the manuscript. All authors read and approved the final manuscript.

\section{Acknowledgement}

The authors would like to greatly acknowledge Addis Ababa Public Health Research and Emergency Management (AAPHREM) for creating and facilitating this research opportunity.

\section{References}

1. Patil AA and Dalal PJ (2016) Bacterial Profile and Resistance Pattern of Bacterial Isolates from Blood Culture. EJPMR 3: 563-567.

2. Wasihun AG, Wlekidan LN, Gebremariam SA, Dejene TA, Welderufael AL, et al. (2015) Bacteriological Profile and Antimicrobial Susceptibility Patterns of Blood Culture Isolates among Febrile Patients in Mekelle Hospital, Northern Ethiopia. Springerplus 4: 314

3. Gohel K, Jojera A, Soni S, Gang S, Sabnis R, et al. (2014) Bacteriological Profile and Drug Resistance Patterns of Blood Culture Isolates in a Tertiary Care Nephrourology Teaching Institute. BioMed Res Int 5.

4. Asrat D, Amanuel YW (2001) Prevalence and Antibiotic Susceptibility Pattern of Bacterial isolates from Blood Culture in Tikur Anbessa Hospital, Addis Ababa Ethiopia. Ethiop Med J 2: 97-104.

5. Van Leth F, Leopold SJ, Tarekegn H, Schultsz C (2014) Antimicrobial drug resistance among clinically relevant bacterial isolates in sub-Saharan Africa: a systematic review. J Antimicrob Chemother 69:2337-2353.

6. Yin Q, Yue D, Peng Y, Liu Y, Xiao L (2013) Occurrence and Distribution of Antibiotic-Resistant Bacteria and Transfer of Resistance Genes in Lake Taihu. Microbes Environ 28: 479-486.

7. Laxminarayan R, Duse A, Wattal C, Zaidi AKM, Wertheim HFL, et al. (2013) Antibiotic Resistance the need for Global Solutions. Lancet Infect Dis 13: 1057-1098.

8. Ntirenganya C, Manzi O, Muvunyi CM, Ogbuagu O (2015) High Prevalence of Antimicrobial Resistance among Common Bacterial isolates in a Tertiary Healthcare Facility in Rwanda. Am J Trop Med Hyg 92: 865-870.

9. Zeki C, Murat K, Osman A (2015) Prevalence and AntimicrobialResistance of Staphylococcus Aureus isolated from Blood Culture in University Hospital, Turkey. Glob J Infect Dis Clin Res 1: 010-013.
10. WHO (2014) Antimicrobial Resistance Global Report on Surveillance

11. Pa W (2016) Performance standards of antimicrobial susceptibility. National Committee for Clinical Laboratory Standards National Committee for Clinical Laboratory Standards approved standards.

12. Karunakaran R, Raja NS, Ng KP, Navaratnam P (2007) Etiology of Blood Culture isolates among Patients in a Multidisciplinary Teaching Hospital in Kuala Lumpur. J Microbiol Immunol Infect 40: 432-437.

13. Zenebe T, Kannan S, Yilma D, Beyene G (2011) Invasive Bacterial Pathogens and their Antibiotic Susceptibility Patterns in Jimma University Specialized Hospital, Jimma, South West Ethiopia. Ethiop J Health Sci 21: 1-8.

14. Dagnew M, Yismaw G, Gizachew M, Gadisa A, Abebe T, et al. (2013) Bacterial Profile and Antimicrobial Susceptibility Pattern in Septicemia Suspected Patients Attending Gondar University Hospital, Northwest Ethiopia. BMC Res Notes 6: 283.

15. Nwadioha SI, Nwokedi EOP, Kashibu E, Odimayo MS, Okwori EE (2010) A Review of Bacterial Isolates in Blood Cultures of Children with Suspected Septicemia in a Nigerian. Afr J Microbiol Res 4: 222-225.

16. Gill MK, Sharma S (2016) Bacteriological Profile and Antibiotic Resistance Pattern in Blood Stream Infection in Critical Care Units of A Tertiary Care Hospital in North India. Indian J Microbiol Res 3: 270-274.

17. Pal N, Sujatha R (2016) Microbiological Profile and Antimicrobial Resistant Pattern of Blood Culture Isolates, Among Septicaemia Suspected Patients. NJLM 5: 17-21.

18. Kingsley OC, Ifeanyi AO, Edet AE, Smart OC (2013) Bacteriological Profile and Antibiotics Susceptibility Pattern of Suspected Septicaemic Patients in Uyo, Nigeria. Res J Med Sci 7: 35-39.

19. Mulu W, Kibru G, Beyene G, Damtie M (2012) Postoperative Nosocomial Infections and Antimicrobial Resistance Pattern of Bacteria Isolates among Patients admitted at Felege Hiwot Referral Hospital, Bahirdar, Ethiopia. Ethiop J Health Sci 22: 7-18.

20. Kabwe M, Tembo J, Chilukutu L, Chilufya M, Ngulube F, et al. (2016) Etiology, Antibiotic Resistance and Risk Factors for Neonatal Sepsis in A Large Referral Center in Zambia. Pediatr Infect Dis J 35: e191-e198.

21. World Health Organization (2012) The Evolving Threat of Antimicrobial Resistance Options for Action. World Health Organization.

22. Boh JAR (2015) Antimicrobial Resistance - A Global Epidemic.

23. O'Neill J (2014) The Review on Antimicrobial Resistance.

24. Ali J, Kebede Y (2008) Frequency of Isolation and Antimicrobial Susceptibility Pattern of Bacterial Isolation from Blood Culture in Gondar University Hospital. Ethio Med J 46: 155-161. 